\title{
Bovine CNS Myelin Contains Neurite Growth-Inhibitory Activity Associated with Chondroitin Sulfate Proteoglycans
}

\author{
Barbara P. Niederöst, ${ }^{1}$ Dieter R. Zimmermann, ${ }^{2}$ Martin E. Schwab, ${ }^{1}$ and Christine E. Bandtlow ${ }^{1}$ \\ ${ }^{1}$ Brain Research Institute, University of Zürich and Swiss Federal Institute of Technology, Zürich, Winterthurerstrasse 190, \\ $\mathrm{CH}-8057$ Zürich, Switzerland, and 2Molecular Biology Laboratory, Department of Pathology, University Hospital, \\ Schmelzbergstrasse 12, CH-8091 Zürich, Switzerland
}

The absence of fiber regrowth in the injured mammalian CNS is influenced by several different factors and mechanisms. Besides the nonconducive properties of the glial scar tissue that forms around the lesion site, individual molecules present in CNS myelin and expressed by oligodendrocytes, such as NI35/NI-250, bNI-220, and myelin-associated glycoprotein (MAG), have been isolated and shown to inhibit axonal growth. Here, we report an additional neurite growth-inhibitory activity purified from bovine spinal cord myelin that is not related to bNI-220 or MAG. This activity can be ascribed to the presence of two chondroitin sulfate proteoglycans (CSPGs), brevican and the brain-specific versican V2 splice variant. Neurite outgrowth of neonatal cerebellar granule cells and of dorsal root ganglion neurons in vitro was strongly inhibited by this myelin fraction enriched in CSPGs. Immunohistochemical staining revealed that brevican and versican V2 are present on the surfaces of differentiated oligodendrocytes. We provide evidence that treatment of oligodendrocytes with the proteoglycan synthesis inhibitors $\beta$-xylosides can strongly influence the growth permissiveness of oligodendrocytes. $\beta$-Xylosides abolished cell surface presentation of brevican and versican V2 and reversed growth cone collapse in encounters with oligodendrocytes as demonstrated by time-lapse video microscopy. Instead, growth cones were able to grow along or even into the processes of oligodendrocytes. Our results strongly suggest that brevican and versican V2 are additional components of CNS myelin that contribute to its nonpermissive substrate properties for axonal growth. Expression of these CSPGs on oligodendrocytes may indicate that they participate in the restriction of structural plasticity and regeneration in the adult CNS.

Key words: neurite growth inhibition; CNS myelin; chondroitin sulfate proteoglycans; oligodendrocyte; regeneration; spinal cord
Although the postnatal mammalian nervous system allows a limited degree of plasticity of fiber circuits that permits short-range rearrangements in connectivity, there is no evidence of changes in the main direction of long axonal projections once development is completed. Similarly, injuries to the mature mammalian brain and spinal cord are followed by permanent deficits because of a lack of regrowth of severed fiber tracts. One of the main impediments to axonal growth appears to be the nonconducive environment of central white matter, because peripheral nerve transplants into the adult mammalian CNS were shown to provide adequate substrate properties for growth of injured CNS fiber tracts (David and Aquayo, 1981; Friedman and Aguayo, 1985). In particular, the presence of the neurite growth-inhibitory molecules NI-35/250 associated with oligodendrocyte membranes and myelin sheaths (Caroni and Schwab, 1988a; Spillmann et al., 1998) is thought to play an important role for the lack of fiber regeneration and the limited plastic responses in the adult mammalian CNS. The monoclonal antibody (mAb) IN-1 raised against these proteins was shown to neutralize their growth-

\footnotetext{
Received June 4, 1999; revised July 26, 1999; accepted Aug. 2, 1999.

This work was supported by Swiss National Science Foundation Grants 3142299.94 and 31-45549.95 to C.E.B. and M.E.S., by the Maurice E. Müller Foundation (Berne), the Dr. Eric Slack-Gyr Foundation (Zürich), the Binelli-Ehrsam Foundation (Zürich), and grants from the Krebsliga des Kanton Zürich, the Lydia Hochstrasser Foundation, and the Swiss National Science Foundation to D.R.Z. We thank R. Schöb for assistance with the photomicrographs, Dr. Y. Yamaguchi for providing the anti-brevican, Dr. U. Rauch for providing the anti-neurocan antibody, and Dr. A. Faissner for providing the anti-tenascin antibodies.

Correspondence should be addressed to Dr. Christine Bandtlow, University of Zürich, Brain Research Institute, Winterthurerstrasse 190, 8057 Zürich, Switzerland. Copyright (C) 1999 Society for Neuroscience 0270-6474/99/198979-11\$05.00/0
}

inhibitory effects in vitro and in vivo, resulting in long-distance fiber growth and increased plastic sprouting within the adult CNS (Caroni and Schwab, 1988b; Bandtlow et al., 1990; Schnell and Schwab, 1990; Bregman et al., 1995; Thallmair et al., 1998; Z'Graggen et al., 1998). Besides NI35/250, myelin-associated glycoprotein (MAG), another myelin component, can inhibit fiber growth of a variety of neuronal cells in culture (McKerracher et al., 1994; Mukhopadhyay et al., 1994; Li et al., 1996). The physiological importance of MAG for axonal regeneration in the CNS, however, is still controversial; one study reports an enhancement of axonal regeneration in $\mathrm{MAG}^{-/-}$mice ( $\mathrm{Li}$ et al., 1996), whereas another study shows no such improvement (Bartsch et al., 1995).

More recently, proteoglycans, cell surface molecules, and constituents of the extracellular matrix were shown to act on axonal growth in vitro. In particular, chondroitin sulfate proteoglycans (CSPGs) can inhibit neurite outgrowth from various neuronal cell types (Carbonetto et al., 1983; Snow et al., 1990a,b; Fichard et al., 1991; Dou and Levine, 1994; Friedlander et al., 1994; Yamada et al., 1997). These properties are often associated with the glycosaminoglycan (GAG) moieties of these molecules but are sometimes found to reside in the protein backbone of the core protein (Katoh-Semba and Oohira, 1993; Dou and Levine, 1994). Although these in vitro studies indicate a functional role of proteoglycans in axonal pattern formation, the in vivo evidence is rather sparse. Recent observations show, however, that distinct proteoglycans are expressed in discrete areas, such as in the roof plate of the developing spinal cord (Snow et al., 1990a; MeyerPuttlitz et al., 1996), the optic fissure (Snow et al., 1991), and in 
posterior somites (Landolt et al., 1995) in which they may act as barriers to axon advance.

In this paper, we describe the presence of an additional inhibitory activity for neurite growth in bovine myelin, identified as the CSPGs brevican and versican V2. Both molecules are expressed by differentiated oligodendrocytes in vitro and contribute to the contact-mediated growth cone collapse of extending neurites.

\section{MATERIALS AND METHODS}

Reagents. Monoclonal antibody IN-1 against the myelin components NI-35/250 and monoclonal antibody O-1 were described previously (Sommer and Schachner, 1981; Caroni and Schwab, 1988b). Polyclonal antibodies $\mathrm{GAG} \alpha$ and $\mathrm{GAG} \beta$ recognizing V2/V0 and V1/V0 splice variants of versican, respectively, were described by Dours-Zimmermann and Zimmermann (1994) and Schmalfeldt et al. (1998). Monoclonal antibody CS56 against chondroitin sulfate proteoglycans was purchased from Sigma (Buchs, Switzerland). Polyclonal antibodies against rat brevican (Yamada et al., 1994) were a kind gift of Dr. Y. Yamaguchi (The Burnham Institute, San Diego, CA), polyclonal anti-MAG antibodies were kindly provided by Dr. J. Salzer (Department of Cell Biology, New York University Medical Center, New York, NY), polyclonal antitenascin antibodies were a kind gift of Dr. A. Faissner (Department of Neurobiology, University of Heidelberg, Heidelberg, Germany), and polyclonal anti-neurocan antibodies were from Dr. U. Rauch (Experimental Pathology, Lund University, Lund, Sweden). The monoclonal antibody Forse-1 recognizing phosphacan (Allendoerfer et al., 1995) was obtained from the Developmental Studies Hybridoma Bank (University of Iowa, Iowa City, IA).

Tissue culture. Dorsal root ganglia were isolated from embryonic day 15 (E15) chicken. Ganglia were cleaned, cut into smaller pieces, and placed in DMEM-F-12 medium (Life Technologies, Gaithersburg, MD) containing $10 \%$ fetal bovine serum (FBS), $2 \%$ chick serum (Life Technologies), and $50 \mathrm{ng} / \mathrm{ml}$ nerve growth factor. Cerebellar granule cells were purified from trypsin dissociates of postnatal day 5-8 rat cerebellar on discontinuous Percoll gradients as described previously by Hatten (1985). Neurons were seeded on poly-L-lysine-coated culture dishes (20,000 cells per well) in DMEM-F-12 medium supplemented with N1 (Sigma), 1\% FBS, and $20 \mathrm{ng} / \mathrm{ml}$ bFGF. Rat oligodendrocyte cultures were obtained by a modified procedure of McCarthy and DeVellis (1980). Briefly, mixed glial cells of newborn rat pubs were grown for 9-11 $\mathrm{d}$ in DMEM-F-12 medium containing $10 \%$ FBS. To dislodge microglial cells, primary cultures were shaken horizontally for $2-3 \mathrm{hr}$ at $200 \mathrm{rpm}$ at $37^{\circ} \mathrm{C}$. Dislodged cells were removed, fresh medium was added, and cultures were shaken overnight at $250 \mathrm{rpm}$. Cells were harvested by pelletation, resuspended in DMEM-F-12 supplemented with N1 and 15 nM triiodothyronine (all from Sigma), and grown for 3-4 d on poly-Llysine at a density of $10^{4}$ cells $/ \mathrm{cm}^{2}$. For encounter experiments with DRG neurons, oligodendrocytes were grown in either the absence or presence of proteoglycan synthesis inhibitors (1.5 mM methylumbelliferyl $\beta$-D-xyloside or $1.5 \mathrm{~mm}$ methyl- $\beta$-D-xylopyranoside; Sigma) for $5 \mathrm{~d}$. Chick DRG explants were then added to the cultures in the absence of inhibitors, and cultures were investigated the next day by time-lapse video microscopy as described previously (Bandtlow et al., 1990, 1993).

Myelin preparation from bovine spinal cord. Bovine spinal cords were obtained from the slaughterhouse, removed from meninges, and cut into pieces of 20-30 gm (wet weight) for homogenization in $0.25 \mathrm{M}$ sucroseHEPES buffer, $\mathrm{pH} 7.2$, including various protease blockers, such as $1 \mathrm{~mm}$ $\mathrm{PhMeSO}_{2} \mathrm{~F}, 2.5 \mathrm{~mm}$ iodoacetamide, $1 \mathrm{~mm}$ EDTA, $2 \mu \mathrm{g} / \mathrm{ml}$ aprotinin, 1 $\mu \mathrm{g} / \mathrm{ml}$ pepstatin, and $1 \mu \mathrm{g} / \mathrm{ml}$ bestatin. The homogenate was first centrifuged at $2000 \mathrm{rpm}$ in a Sorvall HB-4 rotor for $10 \mathrm{~min}$ to remove cell debris and nuclei and then fractionated on a sucrose density gradient as described previously (Colman et al., 1982). After centrifugation for $4 \mathrm{hr}$, the resultant interface was collected, dispersed in $20 \mathrm{vol}$ of $20 \mathrm{~mm}$ HEPES, pH 7.4, and centrifuged in a TI60 rotor (Beckman Instruments, Fullerton, CA) at $24000 \mathrm{rpm}$. The pellet was resuspended in $20 \mathrm{~mm}$ HEPES, pH 7.4, and washed in 10 vol of $100 \mathrm{~mm}$ sodiumcarbonate, $\mathrm{pH}$ 11 , to remove soluble and membrane-associated proteins, before it was neutralized to $\mathrm{pH} 7.4$ and extracted with $2 \%$ Chaps in $20 \mathrm{~mm}$ Tris, $\mathrm{pH}$ 8.0 , and $0.1 \mathrm{M} \mathrm{NaCl}$ in the presence of protease blockers. Protein concentration was determined using the Bradford dye-binding assay (Bio-Rad, Hercules, CA) according to the manufacturer's recommendation with bovine serum albumin (type IV; Bio-Rad) as standard.
Anion exchange chromatography. Extracted proteins were separated by anion exchange chromatography on Q-Sepharose (Amersham Pharmacia Biotech, Uppsala, Sweden) equilibrated in buffer A (20 mM Tris, pH 8.0, $0.1 \mathrm{M} \mathrm{NaCl}$, and $0.5 \%$ Chaps). Proteins were eluted stepwise with buffer $\mathrm{A}$ and increasing ionic strength. After measurement of protein concentration and substrate properties in the various bioassays, active samples containing proteoglycans were pooled and precipitated by 3 vol of ethanol and $1.3 \%$ potassium acetate.

Immunodepletion of versican V2 or brevican from the myelin proteoglycan fraction. Proteoglycan fraction (100-200 $\mu \mathrm{g}$ ) was combined with an equal volume of a polyclonal rabbit antibody specific to bovine versican $\mathrm{V} 2$ or brevican and incubated for $2 \mathrm{hr}$ while rotating at $4^{\circ} \mathrm{C}$. Protein A-conjugated Sepharose beads $(20 \mu \mathrm{l})$, washed three times with $20 \mathrm{~mm}$ Tris, $\mathrm{pH}$ 7.5, $200 \mathrm{~mm} \mathrm{NaCl}$, and $0.5 \%$ Nonidet P-40 containing buffer, were added to the mixture and incubated with rotation at $4^{\circ} \mathrm{C}$ for an additional hour. Lysates were then separated from the beads by centrifugation. Beads were resuspended in $20 \mu \mathrm{l}$ of $20 \mathrm{mM}$ Tris, pH 7.5, $200 \mathrm{~mm}$ $\mathrm{NaCl}, 0.5 \%$ Nonidet P-40, and $1 \%$ SDS containing buffer and pelleted again. Protein concentration was determined in all samples, and $50 \mu \mathrm{g}$ of each fraction was mixed with $100 \mu \mathrm{g} / \mathrm{ml}$ laminin- 1 and analyzed in the neurite outgrowth assay as described above. As a control, purified bovine versican V2 was used as described by Schmalfeldt et al. (1998).

Alcian blue dot-blot assay. To monitor the presence of proteoglycans after anion exchange, an aliquot of each fraction $(2.5$ or $5 \mu \mathrm{g}$ of total protein) was dot-blotted on Gene Screen Plus membranes (DuPont NEN, Wilmington, DE) and stained with Alcian blue according to Buee et al. (1991).

Enzymatic analysis of proteoglycans. Proteoglycan-enriched fractions were digested with protease-free chondroitinase ABC (Boehringer Mannheim, Indianapolis, IN) in $40 \mathrm{~mm}$ Tris, $\mathrm{pH} 8.0,40 \mathrm{~mm}$ sodium acetate, and $0.1 \mathrm{mg} / \mathrm{ml} \mathrm{BSA}$. Typically, $5-8 \mu \mathrm{g}$ of protein were incubated with $0.02 \mathrm{U}$ of chondroitinase $\mathrm{ABC}$ at $37^{\circ} \mathrm{C}$ for $2 \mathrm{hr}$. The reaction mixture was cooled on ice, and $1 \mathrm{mM} \mathrm{CaCl}_{2}$ was added to inactivate the enzyme. In control experiments, samples were treated with heparinase. For every digestion, an aliquot of the reaction mixture was run on a $6 \%$ polyacrylamide gel to monitor completeness of digestion, before samples were tested in the bioassays or used for Western blotting.

SDS-PAGE and immunoblotting. High-resolution SDS-PAGE was performed using $6 \%(\mathrm{w} / \mathrm{v})$ SDS-polyacrylamide gels according to the method of Laemmli (1970). Gels were either silver-stained (Morrissey, 1981) or transferred onto Immobilon-P membranes (Millipore, Bedford, MA) in $20 \mathrm{~mm}$ Trisbase, $192 \mathrm{~mm}$ glycine, $\mathrm{pH}$ 8.3, $0.037 \%$ (w/v) SDS, and $20 \%$ methanol (Towbin et al., 1979) with a semidry transfer apparatus (Trans Blot SD; Bio-Rad). Transfer time was $2 \mathrm{hr}$ at $0.8 \mathrm{~mA} / \mathrm{cm}^{2}$. Blocking reagent ( $1 \mathrm{hr}$ at room temperature) was $3 \%$ gelatin in TBS (20 mM Tris-Cl, pH 7.5, $150 \mathrm{~mm} \mathrm{NaCl}$, and $0.4 \%$ Tween 20 ). Incubation time for the first antibody was usually overnight at $4^{\circ} \mathrm{C}$. HRP-conjugated anti-mouse IgG or anti-rabbit secondary antibody (1:2000) was incubated for $1 \mathrm{hr}$ at room temperature. Finally, the ECL chemiluminescence system was used for detection (Amersham Pharmacia Biotech). Primary antibodies were polyclonal anti-MAG (1:2000), monoclonal IN-1 antibody (hybridoma supernatant; 1:5), polyclonal anti-brevican (1:1000), polyclonal antibody anti-bovine versican GAG $\alpha$ and GAG $\beta$ (1:1000), polyclonal anti-neurocan (1:200), monoclonal anti-phosphacan (hybridoma supernatant 1:5), and monoclonal anti-CS proteoglycan CS56 (1:50).

Neurite outgrowth assay. To determine the growth-modulating properties of the different fractions, $100 \mu \mathrm{l}$ aliquots were evaluated using nitrocellulose-coated four-well Greiner dishes (Greiner, Nürtingen, Germany) according to Lagenaur and Lemmon (1987). Briefly, each well (1 $\left.\mathrm{cm}^{2}\right)$ was coated with $5 \mu$ l of nitrocellulose dissolved in methanol $\left(5 \mathrm{~cm}^{2}\right.$ nitrocellulose in $12 \mathrm{ml}$ of methanol) and air-dried in a tissue culture hood. Test wells were coated for $10 \mathrm{~min}$ with protein fractions of each separation step. After aspiration, wells were washed with DMEM containing $10 \%$ FBS and blocked in that medium for $2 \mathrm{hr}$ at $37^{\circ} \mathrm{C}$, before cerebellar granule cells or chick DRG explants were plated. Assays were stopped after $24 \mathrm{hr}$ in culture by adding $4 \%(\mathrm{w} / \mathrm{v})$ formalin buffered with $\mathrm{NaCl} / \mathrm{P}_{\mathrm{i}}\left(137 \mathrm{mM} \mathrm{NaCl}, 2.7 \mathrm{~mm} \mathrm{KCl}, 1.5 \mathrm{mM} \mathrm{KH} \mathrm{KO}_{4}\right.$, and $8 \mathrm{~mm}$ $\mathrm{Na}_{2} \mathrm{HPO}_{4}, \mathrm{pH}$ 7.4). For assaying inhibitory substrate properties, the proportion of total cells bearing neurites longer than the diameter of the cell body (i.e., neurite outgrowth was successfully initiated) was determined. Under control conditions, in the absence of myelin proteins, $70 \%$ of the cerebellar granule neurons formed processes. To assess neutralization of inhibitory activity, substrate-coated wells were incubated with either the IN-1 hybridoma supernatant or the recombinant Fab fragment (dialyzed against $\mathrm{NaCl} / \mathrm{P}_{\mathrm{i}}$ ) in varying amounts for $20 \mathrm{~min}$ at $37^{\circ} \mathrm{C}$. The 
wells were then washed briefly with HBSS (Life Technologies), and cells were applied in the presence of either the IN-1 containing hybridoma supernatant diluted 1:1 with medium or varying concentrations of Fab fragment. As a control, O1 hybridoma supernatant was used, which recognizes an oligodendrocyte-specific galactocerebroside (Sommer and Schachner, 1981).

Immunocytochemistry of cultured oligodendrocytes. For live-cell staining, unfixed, unpermeabilized oligodendrocyte cultures (grown in either the presence or absence of $\beta$-xylosides) were rinsed in DMEM without serum and then incubated in antibodies against MAG, CS56, brevican, or versican V1/V0 and versican V2/V0, respectively, for $1 \mathrm{hr}$. Cultures were rinsed in DMEM and fixed in $4 \%$ paraformaldehyde before incubation with either FITC-conjugated secondary IgGs to reveal MAG and CS56 staining or with anti-mouse HRP-conjugated secondary antibodies with subsequent reaction with the Vecta-Stain Complex system (Vector Laboratories, Burlingame, CA) according to the manufacture's recommendation to reveal brevican and versican V2. Control experiments showed no cross-reactivity in the absence of the appropriate primary antibodies. To reveal intracellular localization of brevican and versican V2, cultures were fixed in $4 \%$ paraformaldehyde for $10 \mathrm{~min}$, permeabilized in the presence of $0.1 \%$ Triton X-100 for $30 \mathrm{~min}$, and then rinsed in phosphate buffer immediately before antibody staining.

\section{RESULTS}

Previous experiments have led to the identification of MAG (McKerracher et al., 1994) and the neurite growth inhibitor bNI-220 (Spillmann et al., 1998) as the main constituents present in bovine CNS myelin exerting inhibitory neurite growth properties on a variety of neurons in vitro. To identify other neurite growth-inhibitory activities present in myelin of bovine spinal cord, a myelin Chaps extract was chromatographed on a strong anion exchange column. Partially purified cerebellar granule neurons were used in a $24 \mathrm{hr}$ bioassay to test the different fractions for their substrate properties on cell attachment and neurite growth. As shown in Figure $1, B$ and $G$, cell attachment and neurite outgrowth were severely reduced when a CNS myelin Chaps extract $(20 \mu \mathrm{g} / \mathrm{ml})$ was used as a substrate. In contrast, laminin $(10 \mu \mathrm{g} / \mathrm{ml})$ promoted extensive attachment of granule cells and in $70 \%$ of adherent cells, robust neurite growth, with an average neurite length of $70 \mu \mathrm{m}$ (Fig. $1 A, G$ ). As shown previously by us and others (McKerracher et al., 1994; Spillmann et al., 1998), at least three different peaks of inhibitory activity could be eluted with a $\mathrm{NaCl}$ salt step gradient when a spinal cord myelin Chaps extract was fractionated on a strong anion exchange column (Fig. $2 A$ ). Immuno-dot-blots with anti-MAG and anti-bNI-220 (IN-1) antibodies of the separately pooled active fractions revealed that MAG did correlate with inhibitory activity eluting at $150 \mathrm{~mm}$ (peak I), whereas bNI-220 was mainly found in the protein fractions eluting at $400 \mathrm{~mm} \mathrm{NaCl}$ (peak II) (Fig. 2B). Interestingly, neither of the two polypeptides were enriched in the protein peak eluting at high ionic strength (peak III) at $0.8 \mathrm{M} \mathrm{NaCl}$ (Fig. 2B). This observation demonstrates that one or more additional inhibitory activities are present in CNS myelin. Evaluation of the polypeptide profile obtained by $6 \%$ SDS-PAGE showed that the fractions eluting at high ionic strength were enriched in proteins that barely entered the gel and migrated as a broad smear at high molecular weight (Fig. 2C). Semiquantitative dotblot analysis with Alcian blue staining revealed that these fractions were $\sim 10$-fold enriched in proteoglycans (Fig. $2 B$ ) compared with the starting material. Furthermore, Figure $2 C$ shows that digestion with chondroitinase ABC caused the highmolecular weight smear to disappear and increased the relative amount of several components migrating at 400, 320, 180, and 140 $\mathrm{kDa}$. Digestion with heparinase had no effect on the electrophoretic mobility of the high-molecular weight smear (data not shown), indicating a lack of heparin sulfate chains in the sample.
These results demonstrate that several inhibitory activities could be separated form CNS myelin extract and that at least one of these activities seems to be enriched in chondroitin sulfate proteoglycans.

\section{Inhibition of neurite outgrowth of cerebellar granule cells by the proteoglycan-enriched myelin fraction}

As reported previously by us and others, CNS myelin reduces cell adhesion and inhibits neurite outgrowth by at least $80 \%$, as shown in Figure 1, $B$ and $G$, for cerebellar granule neurons. A similar inhibition was observed for neurons grown on a fraction of myelin proteins eluting at high salt (peak III), containing chondroitin sulfate proteoglycans $(10 \mu \mathrm{g} / \mathrm{ml})$ (Fig. $1 D, G)$. Interestingly, the IN-1 antibody, which has been shown to successfully reduce the inhibitory activity exerted by total CNS myelin by $50 \%$ (Fig. $1 C, G$ ) and to completely abolish the effect of bNI-220 (Spillmann et al., 1998), had no apparent effect on the inhibitory activity found in the proteoglycan-enriched myelin fraction (Fig. 1E, $G$ ) or on the MAG-enriched fractions (data not shown). Together with the dot-blot assay (Fig. $2 B$ ), it seems therefore likely that the activity found in peak III results from the proteoglycans and not from a residual contamination of bNI-220 or MAG.

\section{Extending neurites avoid the intact proteoglycan fraction}

To determine whether elongating neurites growing on a growthpromoting substrate avoid surfaces coated with the PG-enriched fractions of peak III, we examined the patterns of neurite growth of chick DRG explants at borders of laminin and the proteoglycan-enriched fraction (peak III). These borders were created by coating half of the nitrocellulose-covered dish with laminin $(10 \mu \mathrm{g} / \mathrm{ml})$ and the other half with protein fractions of peak III $(20 \mu \mathrm{g} / \mathrm{ml})$. Figure 3 demonstrates that, in a choice situation, DRG neurites extending on the laminin surface did not grow over the border into the peak III containing area. Instead, neurites deflected at the border and maintained to grow on the laminin-coated substrate.

These results demonstrate that, in a choice situation, extending DRG neurons avoid areas containing the intact proteoglycanenriched fraction.

\section{CS GAG chains have only moderate influence on the inhibitory activity}

The GAG moieties of proteoglycans have been shown to exert both repulsive and supportive influences on neurite growth in vitro. To determine whether the CS GAG chains are required for the growth-inhibitory activity found associated in peak III, we digested the PG-enriched fractions with chondroitinase ABC and assayed the digestion products for their growth properties on cerebellar granule neurons. As shown in Figure $1, F$ and $G$, only $15 \%$ of the cerebellar granule neurons plated on chondroitinase ABC-digested material were able to put out processes, indicating that the CS chains of the PG-enriched fractions contribute only to a minor extent to the inhibition of neurite growth of cerebellar neurons and that the major activity seems to reside in the protein cores.

\section{Identification of versican V2 and brevican present in the proteoglycan-enriched myelin fraction}

Recent results have provided evidence that a variety of proteoglycans are expressed in the adult brain. In particular, hyalectans, a family of chondroitin sulfate proteoglycans, are most abundant. To identify the components enriched in the proteoglycan frac- 

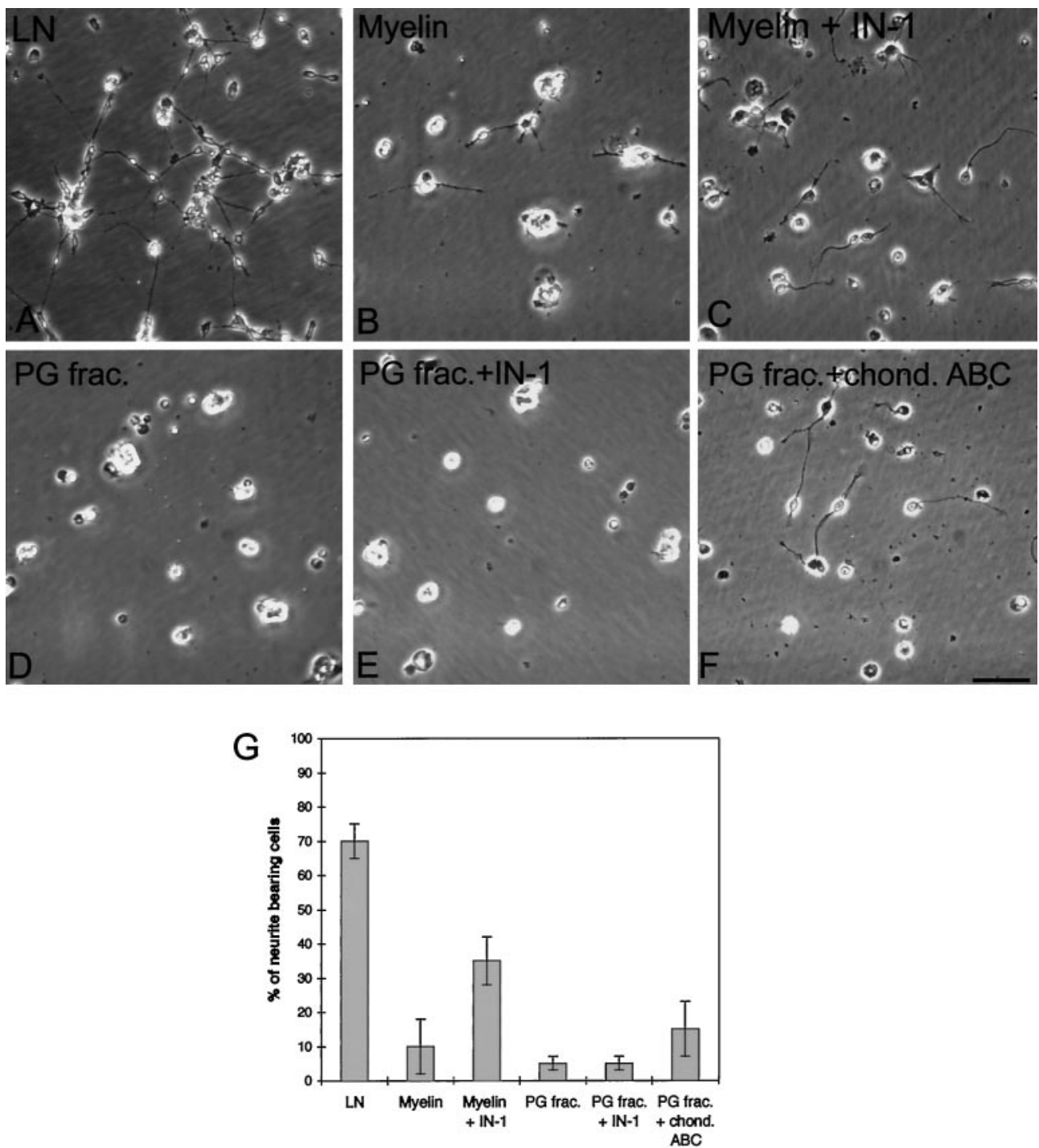

Figure 1. Myelin fractions enriched in proteoglycans do not support cell attachment and neurite outgrowth. Partially purified cerebellar granule neurons were seeded onto nitrocellulose-coated culture dishes absorbed with various myelin fractions as described in Material and Methods and were allowed to grow for $24 \mathrm{hr}$. The substrates are as follows: $A$, laminin $(10 \mu \mathrm{g} / \mathrm{ml}) ; B$, spinal cord myelin Chaps extract $(10 \mu \mathrm{g} / \mathrm{ml}) ; C$, spinal cord myelin Chaps extract $(10 \mu \mathrm{g} / \mathrm{ml})$ preincubated with the mAB IN-1 (1:1); $D$, proteoglycan-enriched myelin fraction $(5 \mu \mathrm{g} / \mathrm{ml}) ; E$, proteoglycan-enriched myelin fraction $(5 \mu \mathrm{g} / \mathrm{ml})$ preincubated with the mAB IN-1 (vol 1:1); $F$, proteoglycan-enriched myelin fraction after chondroitinase ABC treatment. Whereas cell attachment and neurite growth was extensive on laminin, there is reduced adhesion and outgrowth of cells on spinal-cord myelin extract or on a proteoglycan-enriched myelin fraction. Note that the mAB IN-1 could partially neutralize the effect of the spinal cord myelin extract but not of the proteoglycan-enriched myelin fraction. Treatment with chondroitinase $\mathrm{ABC}$ partially abolishes the latter activity. $G$, Quantification of neurite outgrowth of cerebellar granule cells on various substrates. The results are the mean \pm SEM of five independent experiments. $L N$, Laminin-1; myelin, total myelin extract; $P G$, proteoglycan-enriched fraction. Scale bar, $50 \mu \mathrm{m}$.

tions of bovine myelin (peak III), we tested various antibodies against chondroitin sulfate proteoglycan candidates known to be present in the brain. Immunoblotting showed that antibodies against rat brevican react with two bands of 145 and $80 \mathrm{kDa}$ (Fig. 4) on chondroitin ABC-treated protein samples derived from PG-enriched myelin fraction, corresponding to the intact core protein of bovine brevican and its $\mathrm{C}$-terminal proteolytic product (Yamada et al., 1994). In addition, antibody GAG $\alpha$ recognizing the brain-specific V2/V0 splice variant of bovine versican recognized a broad smear in the undigested material and a band at 400 $\mathrm{kDa}$ in the chondroitinase $\mathrm{ABC}$-treated sample, corresponding to the molecular weight of versican V2 purified from bovine brain (Schmalfeldt et al., 1998). Interestingly, antibody GAG $\beta$ recognizing the $\mathrm{V} 1 / \mathrm{V} 0$ versican splice variant did not recognize any specific band, indicating that the larger V0 and V1 splice variants are mainly absent from this myelin fraction and that the $400 \mathrm{kDa}$ band is indeed representing the intact versican V2 core protein. Furthermore, the myelin fraction seemed not to contain any other chondroitin sulfate proteoglycans, such as neurocan or phosphacan (Rauch et al., 1991; Margolis et al., 1996) or any tenascinisoforms because no immunoreactivity could be detected with the corresponding antibodies (data not shown). To exclude that proteins other than versican V2 and/or brevican may contribute to the neurite growth-inhibitory activity found in peak III of bovine CNS myelin, we immunodepleted versican V2 or brevican from this fraction and tested the remaining activity in the in vitro bioassay. As shown in Figure $5 A$, there was a considerable loss of inhibitory activity of peak III, whereas activity was found in the 

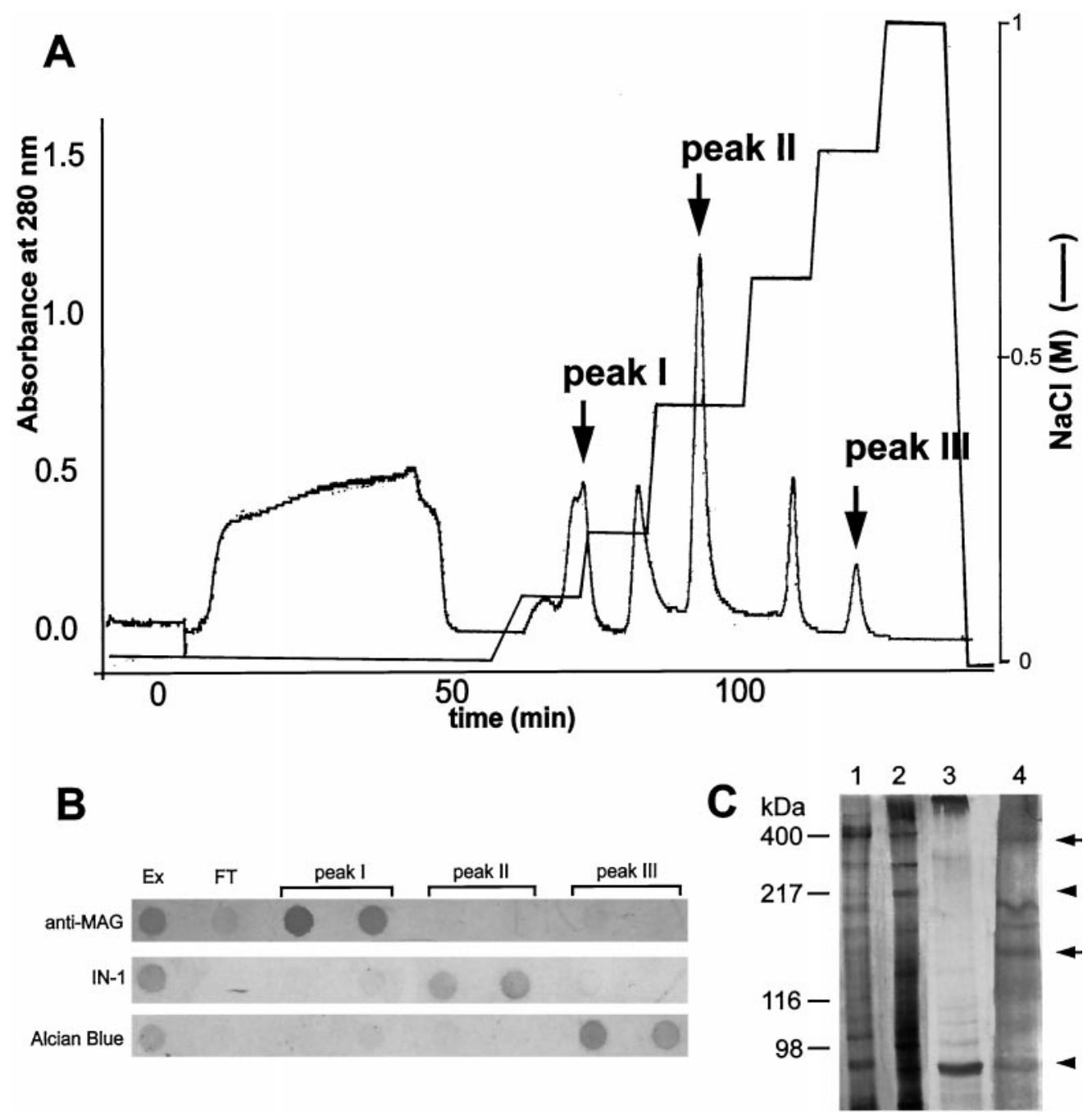

Figure 2. Analysis of neurite growth-inhibitory activity after separation of myelin proteins by anion exchange chromatography. $A$, The elution profile of the Q-Sepharose column is shown. A, Chaps-extract of spinal cord myelin was loaded onto a Q-Sepharose column and eluted by a step salt gradient as indicated $(0.1-1 \mathrm{M} \mathrm{NaCl})$. Activity of each fraction was tested in the bioassay. Three activity peaks (indicated by arrows) eluting at 150 (peak I), 400 (peak II), and 800 (peak III) mM NaCl could be determined. B, Dot-blot profile of active fractions to monitor distribution of myelin-associated neurite growth inhibitors. Active fractions of each peak were pooled, and aliquots of $5 \mu \mathrm{g}$ each were dotted on membranes and probed with anti-MAG, IN-1 antibodies, and Alcian blue, respectively. Note that the presence of MAG correlates with peak I, the IN-1 antigen with peak II, and the enrichment of proteoglycans with peak III. $C$, Aliquots $(2 \mu \mathrm{g} /$ lane $)$ of each activity pool were electrophoresed on $6 \%$ SDS-polyacrylamide gels and visualized by silver staining. Lane 1, Activity peak I; lane 2, activity peak II; lane 3, activity peak III, proteins appear as a mixture of a high-molecular weight smear; lane 4 , activity peak III digested with chondroitinase ABC. Enzyme treatment causes the disappearance of the smear and increases the amount of components at 400, 320, 180, and $140 \mathrm{kDa}$. The mobility of the molecular weight marker is indicated by the arrows to the left. Laminin was used as a marker for $400 \mathrm{kDa}$.

versican V2 immunoprecipitate, even in the presence of laminin-1 (Fig. 5B,E). A similar, although less pronounced, reduction was seen after immunodepletion of brevican (Fig. $5 C, E$ ). Furthermore, we show that purified versican V2 strongly inhibited cerebellar neurite outgrowth under the same experimental conditions (Fig. 5D,E).

Together, these data strongly suggest that versican V2 and brevican are indeed the main components in peak III that cause neurite growth inhibition.

\section{Differentiated oligodendrocytes express brevican and versican V2}

To assess whether differentiated oligodendrocytes express brevican and/or versican on their cell surface, we stained life cultures of enriched oligodendrocytes with antibodies directed against brevican and specific splice variants of versican, respectively. We found that highly branched oligodendrocytes, but also flat cells, which are presumably astrocytes, are immunoreactive for brevican (Fig. 6A) and for versican V2/V0 (Fig. 6B) but not for versican V1/V0 (Fig. $6 C$ ). The surface-associated staining in live-cell labeling experiments showed a distribution very similar to that observed in cultures that had been fixed and permeabilized before staining (Fig. $6 D-F$ ). In addition to the surfaceassociated immunoreactivity, brevican-positive (Fig. 6D) and versican V2/V0-positive (Fig. 6E) cells in fixed and permeabilized preparations showed intracellular immunoreactivity, which was not observed after live labeling. A similar, although weaker, staining pattern was obtained with the CS56 antibody recognizing chondroitin sulfate proteoglycans (Fig. $6 F$ ). No specific intracellular labeling was seen with antibodies against versican V1/V0 (data not shown). The persistence of surface-associated immu- 
A

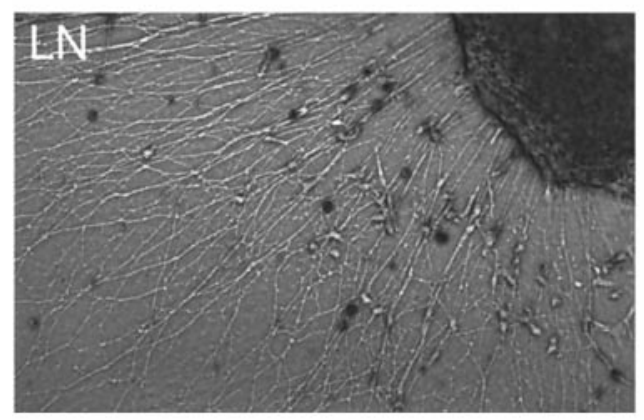

B

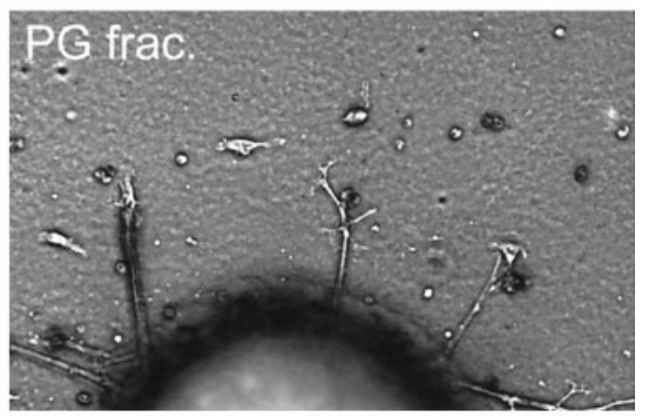

Figure 3. DRG neurites avoid substrates enriched in the proteoglycancontaining myelin fraction in a choice situation. $A, \mathrm{~A}$ chick DRG explant shows robust outgrowth on a laminin substrate $(10 \mu \mathrm{g} / \mathrm{ml}) . B$, The proteoglycanenriched myelin fraction $(10 \mu \mathrm{g} / \mathrm{ml})$ does not support outgrowth of chick DRG neurites. $C$, Neurites of a DRG explant extending on a laminin-substrate do not cross the border (indicated by the dotted line) into the proteoglycan-containing substrate area. Scale bar, $50 \mu \mathrm{m}$.

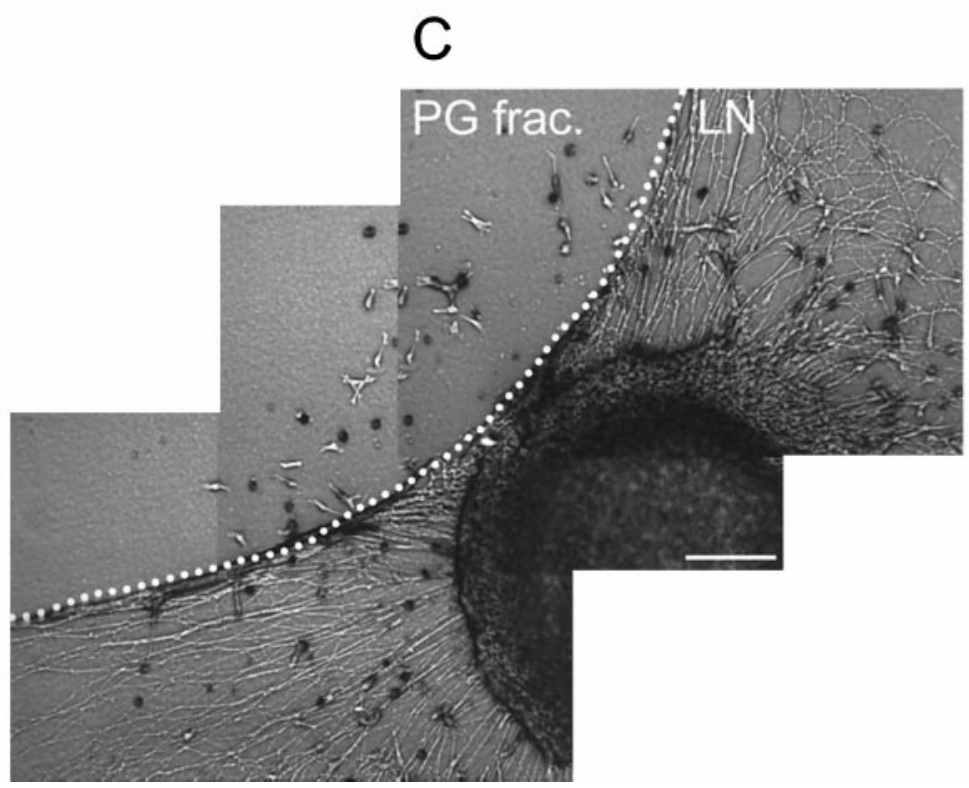

noreactivity on live unpermeabilized cells indicates that the epitopes of both hyalectans are localized to the extracellular surface of the glial membrane.

\section{Increased axon growth over oligodendrocytes grown in the presence of proteoglycan synthesis inhibitors}

Because we have shown that brevican and V2/V0 versican are present on oligodendrocyte surfaces and that the myelin fraction enriched in brevican and versican V2 inhibits neurite outgrowth of cerebellar granule neurons and DRG explants, we tested the relative contribution of these proteoglycans for the contactmediated growth cone collapse. For this purpose, oligodendrocytes were grown in the presence or absence of the proteoglycan synthesis inhibitors methyl-umbelliferyl- $\beta$-D-xyloside or methyl$\beta$-D-xylopyranoside (1.5 mM each). These inhibitors have been shown to interrupt normal proteoglycan synthesis by serving as artificial acceptors for galactosyltransferases. The addition of $\beta$-D-xylosides to cell cultures results in the production of increased amounts of free GAG chains and decreased amounts on intact proteoglycan monomers (Schwartz, 1977). Such a loss of intact proteoglycan production could be revealed by immunostaining of oligodendrocytes with the anti-CS proteoglycan antibody CS56. Oligodendrocytes grown in the absence of $\beta$-Dxylosides showed intense cell surface staining with the CS56 antibody (Fig. 7A). In cultures treated with $\beta$-D-xyloside, there was a pronounced reduction in the surface-associated staining of oligodendrocytes (Fig. $7 B$ ) and a pronounced increase in the intracellular pool of CS56-immunoreactive material seen in fixed-permeabilized cells (data not shown). Moreover, cells showed an increased intracellular staining with anti-brevican and anti-versican V2 antibodies but a reduced cell surface staining (data not shown), indicating a retention of these proteoglycan molecules. To prove that addition of $\beta$-D-xylosides did not result in an overall disruption or change of cell surface protein synthesis, oligodendrocytes were stained with anti-MAG antibodies. As shown in Figure $7 C$, a strong immunopositive signal for MAG was detected on $\beta$-D-xyloside-treated cells, indicating that synthesis of proteins other than proteoglycans is not affected. Interactions of DRG neurites with oligodendrocytes was investigated by video time-lapse microscopy to assess whether treatment of oligodendrocytes with these inhibitors results in a reduced ability of the cells to inhibit neurite growth. In the absence of $\beta$-Dxylosides, growth cones of extending E15 chick DRG neurites collapsed and subsequently retracted on contact with highly branched rat oligodendrocytes, as seen in $\sim 80 \%$ of all encounters (Fig. 7D). However, when oligodendrocytes were grown in the presence of the proteoglycan synthesis inhibitors methylumbelliferyl- $\beta$-D-xyloside or methyl- $\beta$-D-xylopyranoside $(1.5 \mathrm{~mm}$ each), no contact-mediated arrest of growth cones with subsequent collapse was observed $(n=6)$. Instead, growth cones either grew into the oligodendrocyte processes network and then eventually stopped for several hours $(n=5)$ (Fig. $7 F)$ or grew along the margin of the processes and passed the oligodendrocyte by 


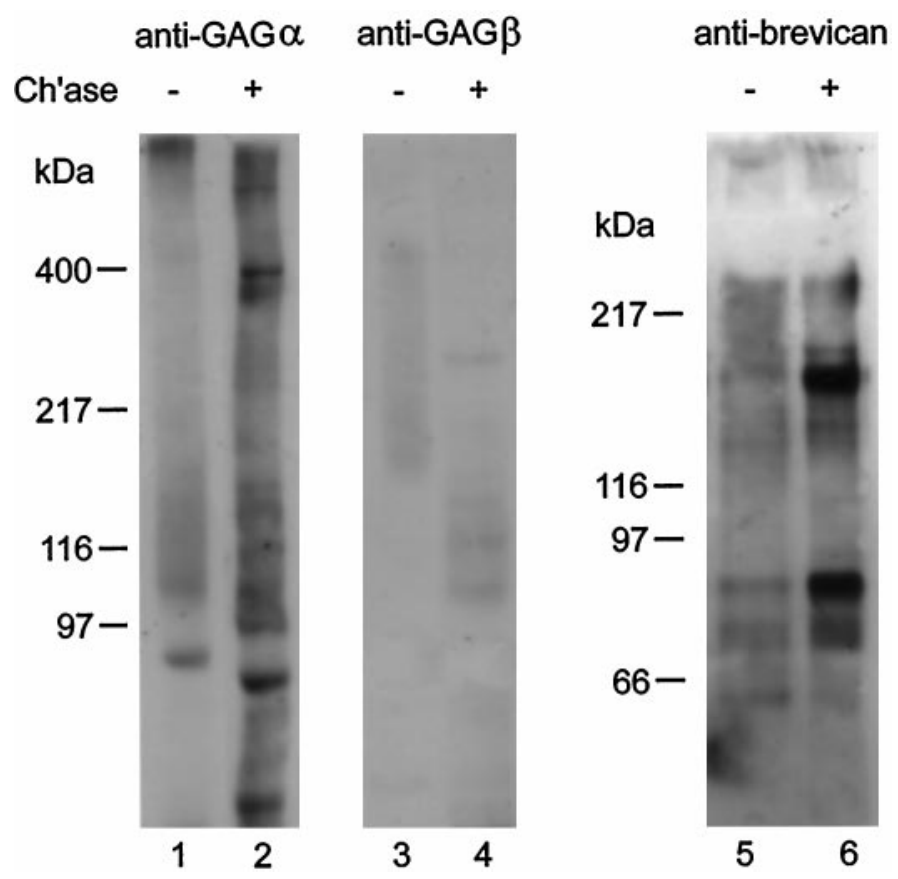

Figure 4. Presence of brevican and versican in proteoglycan-enriched myelin fraction. Aliquots of peak III activity pool (5 $\mu \mathrm{g}$ each) without (lanes 1,3,5) or with (lanes 2, 4,6) chondroitinase ABC digestion were electrophoresed on 5 or $6 \%$ SDS-polyacrylamide gels under nonreducing conditions and immunoblotted with anti-GAG $\alpha$ (1:1000) recognizing V2/V0 bovine versican, GAG $\beta$ (1:1000) recognizing V1/V0 bovine versican, and anti-brevican antibodies (1:1000).

"side-stepping" $(n=5)$ (Fig. $7 E)$. Both types of growth cone reactions indicate that oligodendrocytes have become more permissive for extending neurites when intact proteoglycans are lacking on the cell surface or are retained intracellularly.

\section{DISCUSSION}

In the present in vitro studies, we have attempted to identify components associated with bovine CNS myelin that exert inhibitory substrate properties for neuronal growth. In summary, these studies demonstrate the following: (1) besides the previously described inhibitory molecules MAG and bNI-220, another neurite growth-inhibitory activity is found to be enriched in the CSPGs; (2) the two CSPGs versican V2 and brevican were identified as the main constituents to inhibit neurite outgrowth from cerebellar granule cells and DRG neurons in vitro; (3) both hyalectans are localized on the surface of highly branched oligodendrocytes, cells that have been demonstrated previously to evoke contact-mediated collapse and retraction of growth cones; and (4) oligodendrocytes grown in the presence of proteoglycan synthesis inhibitors are less inhibitory for neurite growth than untreated cells.

Previous studies have reported that CNS myelin extracts chromatographed on an anion-exchange column consistently revealed several peaks of neurite growth-inhibitory activity. This lead to the identification of MAG (McKerracher et al., 1994) and bNI220 (Spillmann et al., 1998) as inhibitory molecules. However, both studies report on the presence of additional inhibitory activities of unknown molecular identity. Here, we demonstrate that the inhibitory activity we identified in the high-salt eluate of CNS myelin is different from either MAG or bNI-220 but accounts from the presence of the two CSPGs brevican and the
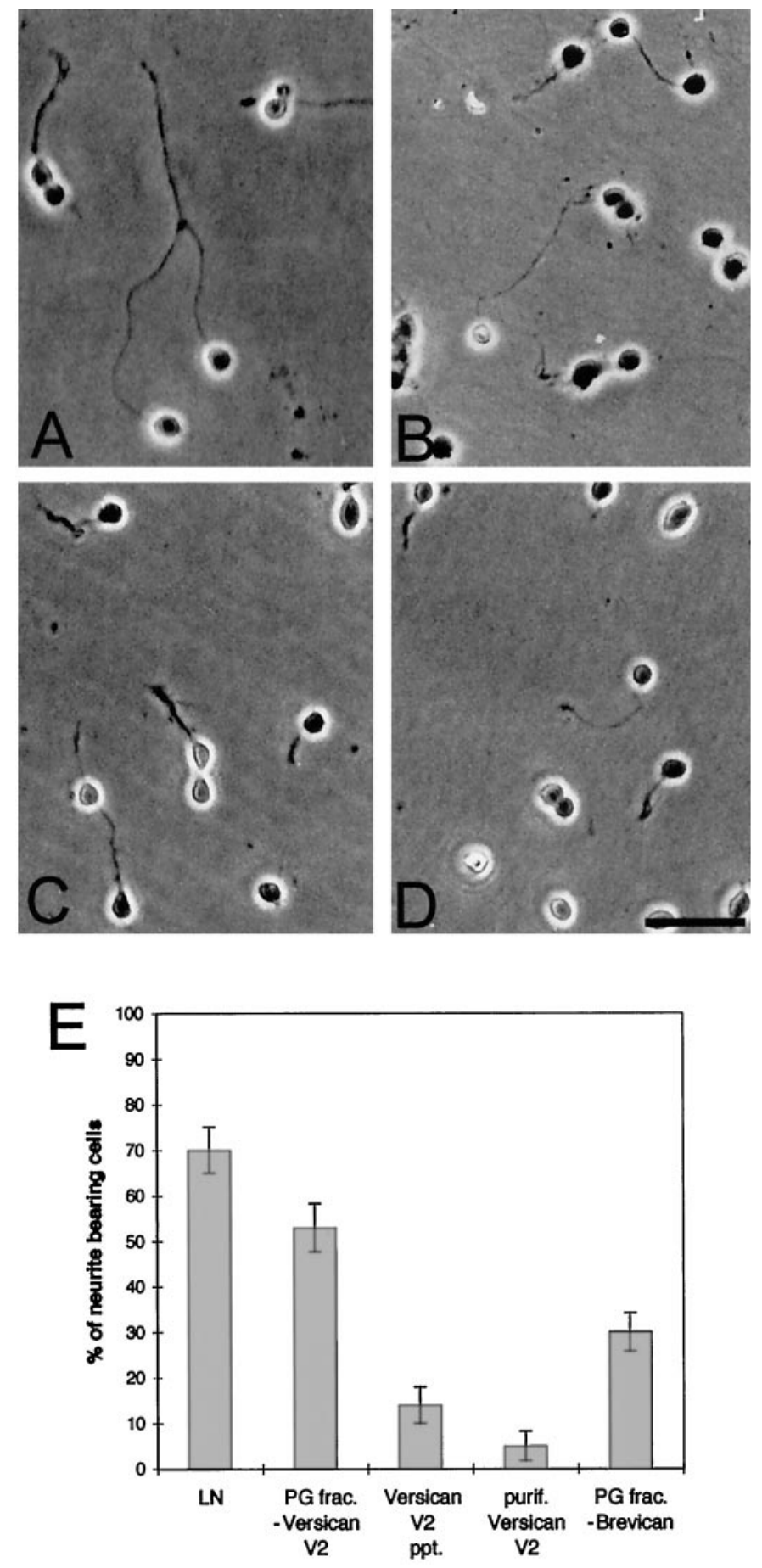

Figure 5. Brevican and versican V2 are the main inhibitors of neurite outgrowth in the proteoglycan-enriched myelin fraction. Cerebellar granule cells were plated on peak III substrate immunodepleted with antiversican V2 $(A)$ or anti-brevican $(C)$ antibodies. In contrast, inhibitory activity is retained in the versican immunoprecipitate $(B)$. Purified versican V2 $(50 \mu \mathrm{g} / \mathrm{ml})$ was used for comparison $(D)$. All tested substrates were supplemented with $100 \mu \mathrm{g} / \mathrm{ml}$ laminin-1. Quantification of these results is shown in $E$. The results are the mean \pm SEM of three independent experiments. Scale bar, $50 \mu \mathrm{m}$.

brain-specific versican splice variant V2/V0. Although we are aware of the presence of additional proteins in the CSPGenriched myelin fraction, several aspects speak against the possibility that they are responsible for the inhibitory activity. First, 

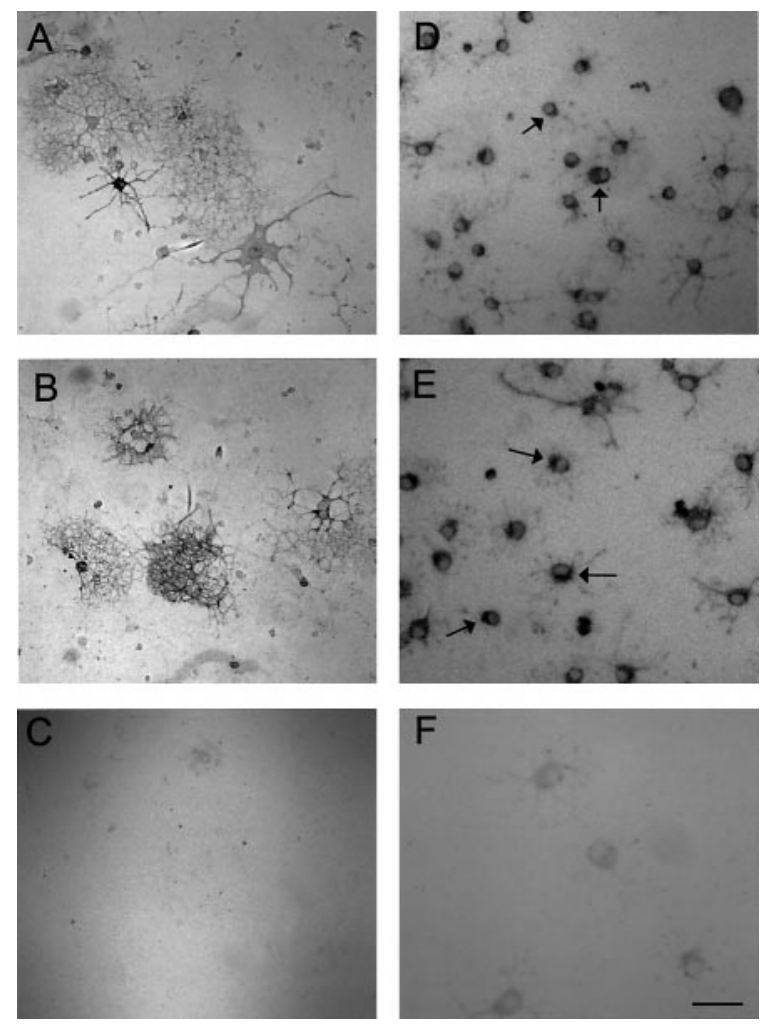

Figure 6. Immunolocalization of brevican and versican on the surface of differentiated oligodendrocytes. Enriched oligodendrocyte cultures were immunostained before $(A-C)$ or after fixation and permeabilization $(D-$ $F)$. Immunostaining was performed with anti-brevican $(A, D)$, antiversican GAG $\alpha$ antibodies $(B, E)$, anti-versican GAG $\beta$ antibodies $(C)$, and CS56 antibodies $(F)$. Immunoreactivity seen in fixed and permeabilized cultures is intracellularly retained (arrows) when cultures are stained after fixation and permeabilization, whereas the intracellular staining is not seen in untreated cultures. This demonstrates that the surfaceassociated brevican and versican V2 staining on differentiated oligodendrocytes and unidentified flat cells (arrowhead) is extracellular. No specific staining of cells was seen with anti-versican GAG $\beta$ antibodies revealing the absence of versican V1/V0. Scale bar, $50 \mu \mathrm{m}$.

immunodepletion of versican, as well as brevican, resulted in a significant loss of the inhibitory activity. It is certainly well known that hyalectans can interact with other proteins, in particular with tenascin-R (Aspberg et al., 1997), a molecule with neurite growth-inhibitory properties (Pesheva et al., 1993). However, the possible coprecipitation of tenascin seems rather unlikely because no tenascin- $\mathrm{R}$ could be immunodetected in the proteoglycanenriched myelin fraction. Second, and most importantly, our study clearly demonstrates that purified versican V2 can inhibit neurite growth of cerebellar granule cells, even in the presence of laminin. Likewise, the present results concur with a recent study showing that soluble brevican can be inhibitory for cerebellar granule cells in vitro (Yamada et al., 1997). The presence of brevican in myelin-associated fractions may not be completely surprising because it was reported recently that the GPI-linked form of brevican was mainly found in membrane preparations from optic nerve (Seidenbecher et al., 1998). Moreover, in situ hybridization revealed a strong expression of glycosylphosphatidylinositol (GPI)-linked brevican in white matter areas of the rat brain (Seidenbecher et al., 1995). At present, the relative abundance of each hyalectan in the myelin fraction and its contribution to the inhibitory activity is difficult to establish. Although the inhibitory activity of brevican seems to reside in the GAG side chains (Yamada et al., 1997), the numerous negatively charged chondroitin sulfate side chains and sialic acid groups of versican V2 are apparently not directly responsible for the inhibitory activity (M. Schmalfeldt, C. E. Bandtlow, M. T. Dours-Zimmermann, K. H. Winterhalter, and D. R. Zimmermann, unpublished observations). Interestingly, the growth inhibition described in this study seems to be relatively independent of the covalently attached CS GAG chains, because digestion of the myelin CSPG fraction with chondroitinase $\mathrm{ABC}$ only moderately altered the ability of the CSPGs to inhibit neurite growth. This observation suggests a higher abundance of versican V2 versus brevican in the myelin CSPG fraction, because otherwise a more drastic decrease in the inhibitory activity would have been expected.

How versican V2 and brevican could inhibit axonal growth remains open. Most likely they would transmit their neurite growth-inhibitory effects through the species-conserved globular domains at the ends of the core protein. Because these domains are present in each of the four splice variants of versican, one would expect a certain degree of redundancy of the versican isoforms with regard to axon growth inhibition. Because the C-terminal domain of hyalectans contains a C-type lectin domain, it is possible that certain cell surface carbohydrates are involved in the interaction with versican and brevican. Recent evidence suggests that this lectin domain binds to the cell surface through an interaction with sulfated glycolipids (Miura et al., 1999), but at present no neuronal ligands for the C-terminal globular domains of brevican and versican has been identified.

In the enriched oligodendrocyte culture system used here, the presence of brevican and versican V2, but not of versican V0/V1 immunoreactivity within oligodendrocytes as well as on their surfaces, is consistent with the idea that this cell type synthesizes brevican and versican V2. However, although the intracellular antigen might reflect production of the CSPGs, we cannot exclude that the positive staining pattern may result from a possible endocytosis of CSPGs produced by contaminating cells. Three lines of evidence indicate that oligodendrocytes are the most likely cellular source of brevican and versican V2. First, because the antibodies used recognize a protein epitope (Yamada et al., 1994; Schmalfeldt et al., 1998), it should be possible to visualize the antigens soon after translation of their protein core. Second, treatment of primary cultures with $\beta$-xylosides, that result in a retention of the proteoglycan core proteins within the endoplasmic reticulum or Golgi, led to an increase in the intracellular, perinuclear brevican and versican V2 immunoreactivity and to a reduced cell surface staining. Similar results have been obtained for the distribution of Cat-105 in cortical cultures treated with $\beta$-xylosides (Lander et al., 1998). Third, both proteins were found to be present in protein fractions purified from myelin as revealed by Western blotting (Fig. 4). Moreover, in situ hybridization studies of versican V2 show a typical oligodendrocyte-specific expression pattern in the cerebellum (Schmalfeldt, Bandtlow, Dours-Zimmermann, Winterhalter, and Zimmermann, unpublished observations). Little is known about the physiological function of versican V2 or brevican in the brain. The relatively late appearance of versican V2 and brevican in the CNS (Yamada et al., 1997; Milev et al., 1998) suggests that their capacity to inhibit axonal growth may be linked to the stabilization of the mature neuronal network rather than to axonal guidance processes. Studies of the developing rat cerebellum demonstrated the expression of brevican on the surface of astrocytes that form neuroglial sheaths surrounding glomeruli in the protoplasmic 

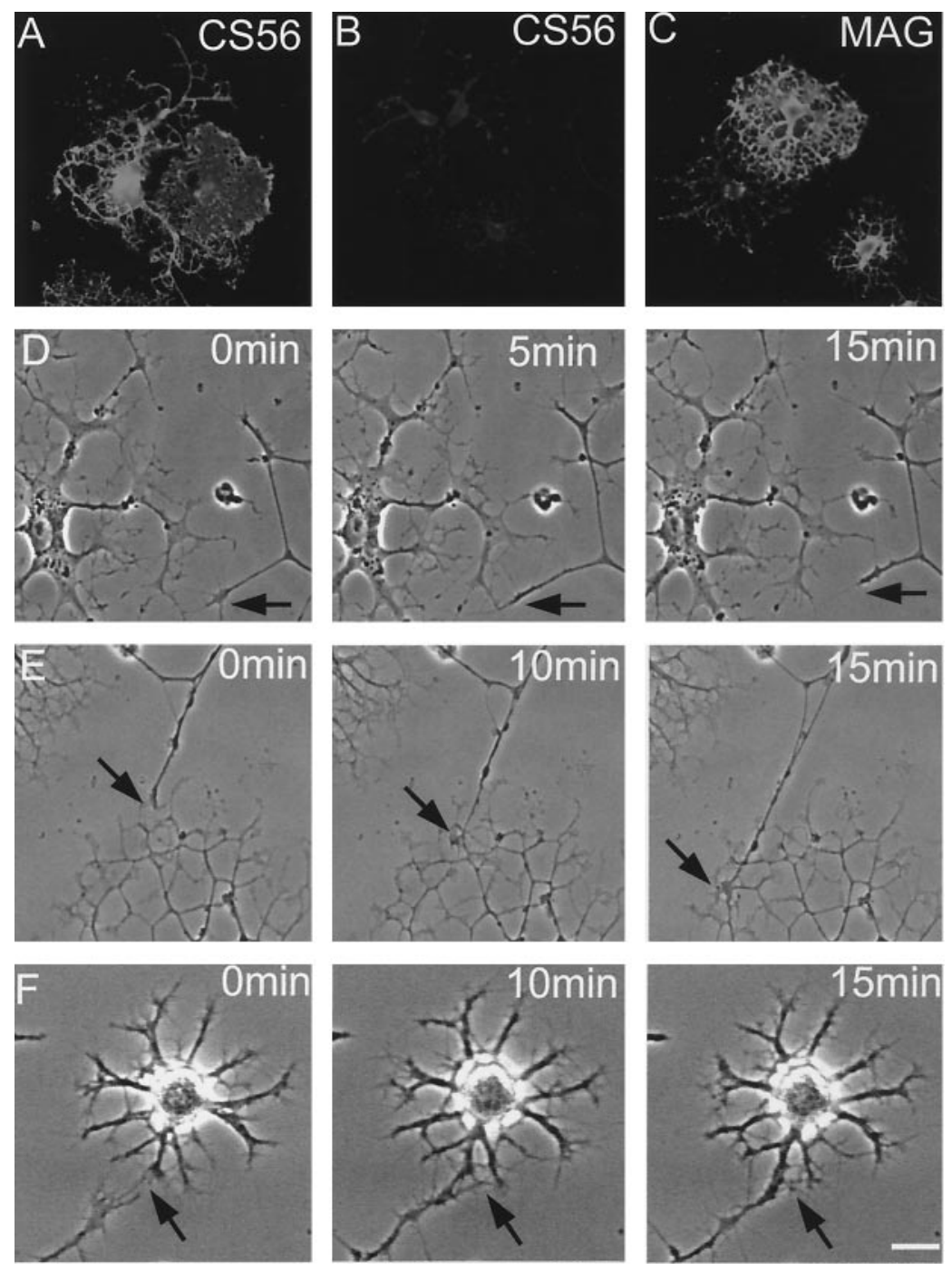

Figure 7. Encounter of chick DRG neurons with oligodendrocytes grown in the absence or presence of proteoglycan synthesis inhibitors. Treatment of oligodendrocyte cultures with $\beta$-xylosides that inhibit the synthesis and/or secretion of CSPGs leads to a retention of CSPG, as revealed with cell surface CS56 immunoreactivity, but has no apparent effect on protein synthesis of cell surface proteins. Primary oligodendrocytes cultures were maintained for $5 \mathrm{~d}$ with $(B, C)$ or without $(A) 1.5 \mathrm{~mm}$ methyl-umbelliferyl- $\beta$-D-xyloside. $A$, Control cultures show robust CS56 surface-associated staining. After $5 \mathrm{~d}$ of $\beta$-D-xyloside treatment, there is a marked decrease in CS56 cell surface labeling of oligodendrocytes $(B)$ but no apparent reduction of MAG staining $(C) . D-F$ shows time-lapse sequences of chick E15 DRG growth cones encountering differentiated oligodendrocyte grown in the absence $(D)$ or presence $(E, F)$ of $1.5 \mathrm{~mm}$ methylumbelliferyl- $\beta$-D-xyloside. Note that contact of differentiated oligodendrocytes leads to arrest and subsequent collapse of the growth cone $(D)$. No such response is seen on contact with $\beta$-D-xyloside-treated oligodendrocytes $(E, F)$. Instead, growth cones grew either into the oligodendrocyte processes network and then eventually stopped for several hours $(F)$ or they grew along the margin of the processes and passed the oligodendrocyte by side-stepping $(E)$. islets of the granule cell layer (Yamada et al., 1997). Because mossy fibers form synapses with other neurons of the cerebellum within such glomeruli, it was suggested that brevican may restrict the infiltration of axons and dendrites into maturing glomeruli (Yamada et al., 1997). A more recent immunohistochemical report demonstrated that brevican and hyaluronan are also present in perineuronal nets in a number of nuclei of postnatal rat brain, often colocalized with tenascin-R (Hagahira et al., 1999). Although the physiological relevance of such perineuronal nets is mainly unknown, their postnatal appearance suggests a role in preventing the establishment of new synaptic contacts. The assembly of a hyalectan-associated matrix on the surface of mature neurons may provide such a barrier against further synapse formations. Similarly, the expression of versican V2 in white matter areas (Schmalfeldt, Bandtlow, Dours-Zimmermann, Winterhalter, and Zimmermann, unpublished observations) and its presence with brevican in CNS myelin suggests a role in restricting structural plasticity and regeneration of CNS fiber tracts. The capacity for plasticity and regeneration in the CNS decreases during postnatal development (Kuang and Kalil, 1990; Firkins et al., 1993), a process that coincides in time with the formation of myelin (Kapfhammer and Schwab, 1994). Interestingly, prevention of myelin formation in the spinal cord results in the persistence of the sprouting capacity in adult rats (Schwegler et al.,
1995; Vanek et al., 1998). Previous studies have shown that the inhibitory effect of CNS myelin on fiber outgrowth, sprouting, and regeneration is caused by the presence of growth-inhibitory molecules, such as MAG, NI-35/250, and bNI-220 (Caroni and Schwab, 1988a; Bandtlow et al., 1990; McKerracher et al., 1994; Spillmann et al., 1998) (for review, see Schwab and Bartholdi, 1996). In particular, the presence of NI-35/250 and MAG on rat oligodendrocytes is thought to be responsible for the contactmediated collapse of growth cones encountering oligodendrocytes (Bandtlow et al., 1990, 1993; Shibata et al., 1998). The present data show that the inhibition of proteoglycan synthesis with $\beta$-xylosides makes primary oligodendrocytes more permissive to neurite outgrowth, indicating that proteoglycans, such as brevican and versican, associated at the cell surface are also involved in the inhibitory effect. It is interesting to note that, in the presence of $\beta$-xylosides, contact-mediated growth cone collapse was abolished, despite the presence of MAG on the oligodendrocyte surface. Whether inhibition of proteoglycan synthesis acts indirectly by interfering with the proper presentation of MAG and possibly also of NI-35/250 remains open. Nevertheless our findings suggest that a fine balance in the relative abundance of each constituent is required to evoke contact-mediated growth cone collapse.

Together, our results suggest that brevican and versican V2 may 
act as additional components restricting structural plasticity in the nervous system and preventing the infiltration of excess numbers of dendrites and axons into target areas. Furthermore, our results suggest that modifying the CNS extracellular matrix by alternating its proteoglycan composition might have a considerable effect on the regenerative capacity of axons.

\section{REFERENCES}

Allendoerfer KL, Magnani JL, Patterson PH (1995) FORSE-1, an antibody that labels regionally restricted subpopulations of progenitor cells in the embryonic central nervous system, recognizes the Le(x) carbohydrate on a proteoglycan and two glycolipid antigens. Mol Cell Neurosci 6:381-395.

Aspberg A, Miura R, Bourdoulous S, Shimonaka M, Heinegard D, Schachner M, Ruoslahti E, Yamaguchi Y (1997) The C-type lectin domains of lecticans, a family of aggregating chondroitin sulfate proteoglycans, bind tenascin-R by protein-protein interactions independent of carbohydrate moiety. Proc Natl Acad Sci USA 94:10116-10121.

Bandtlow CE, Zachleder T, Schwab ME (1990) Oligodendrocytes arrest neurite growth by contact inhibition. J Neurosci 10:3837-3848.

Bandtlow CE, Schmidt MF, Hassinger TD, Schwab ME, Kater SB (1993) Role of intracellular calcium in NI-35-evoked collapse of neuronal growth cones. Science 259:80-83.

Bartsch U, Bandtlow CE, Schnell L, Bartsch S, Spillmann AA, Rubin BP, Hillenbrand R, Montag D, Schwab ME, Schachner M (1995) Lack of evidence that myelin-associated glycoprotein is a major inhibitor of axonal regeneration in the CNS. Neuron 15:1375-1381.

Bregman BS, Kunkel-Bagden E, Schnell L, Dai NH, Gao D, Schwab ME (1995) Recovery from spinal cord injury mediated by antibodies to neurite growth inhibitors Nature 378:498-501.

Buee L, Boyle NJ, Zhang LB, Delacourte A, Fillit HM (1991) Optimization of an Alcian blue dot-blot assay for the detection of glycosaminoglycans and proteoglycans. Anal Biochem 195:238-242.

Carbonetto S, Gruver MM, Turner DC (1983) Nerve fiber growth in culture on fibronectin, collagen, and glycosaminoglycan substrates. J Neurosci 3:2324-2335.

Caroni P, Schwab ME (1988a) Antibody against myelin-associated inhibitor of neurite growth neutralizes nonpermissive substrate properties of CNS white matter. Neuron 1:85-96.

Caroni P, Schwab ME (1988b) Two membrane protein fractions from rat central myelin with inhibitory properties for neurite growth and fibroblast spreading. J Cell Biol 106:1281-1288.

Colman DR, Kreibich G, Frey AB, Sabatini DD (1982) Synthesis and incorporation of myelin polypeptides into CNS myelin. J Cell Biol 95:598-608.

David S, Aguayo AJ (1981) Axonal elongation into peripheral nervous system "bridges" after central nervous system injury in adult rats. Science 214:931-933.

Dou CL, Levine JM (1994) Inhibition of neurite growth by the NG2 chondroitin sulfate proteoglycan. J Neurosci 14:7616-7628.

Dours-Zimmermann MT, Zimmermann DR (1994) A novel glycosaminoglycan attachment domain identified in two alternative splice variants of human versican. J Biol Chem 269:32992-32998.

Fichard A, Verna JM, Olivares J, Saxod R (1991) Involvement of a chondroitin sulfate proteoglycan in the avoidance of chick epidermis by dorsal root ganglia fibers: a study using $\beta$-D-xyloside. Dev Biol 148:1-9.

Firkins SS, Bates CA, Stelzner DJ (1993) Corticospinal tract plasticity and astroglial reactivity after cervical spinal injury in the postnatal rat. Exp Neurol 120:1-15.

Friedlander DR, Milev P, Karthikeyan L, Margolis RK, Margolis RU, Grumet M (1994) The neuronal chondroitin sulfate proteoglycan neurocan binds to the neural cell adhesion molecules Ng-CAM/L1/NILE and N-CAM, and inhibits neuronal adhesion and neurite outgrowth. J Cell Biol 125:669-680.

Friedman B, Aguayo AJ (1985) Injured neurons in the olfactory bulb of the adult rat grow axons along grafts of peripheral nerve. J Neurosci 5:1616-1625.

Hagihara K, Miura R, Kosaki R, Berglund E, Ranscht B, Yamaguchi Y (1999) Immunohistochemical evidence for the brevican-tenascin-R interaction: colocalization in perineuronal nets suggests a physiological role for the interaction in the adult rat brain. J Comp Neurol 410:256-264.

Hatten ME (1985) Neuronal regulation of astroglial morphology and proliferation in vitro. J Cell Biol. 100:384-396.
Kapfhammer JP, Schwab ME (1994) Inverse patterns of myelination and GAP-43 expression in the adult CNS: neurite growth inhibitors as regulators of neuronal plasticity? J Comp Neurol 340:194-206.

Katoh-Semba R, Oohira A (1993) Core proteins of soluble chondroitin sulfate proteoglycans purified from the rat brain block the cell cycle of PC12D cells. J Cell Physiol 156:17-23.

Kuang RZ, Kalil K (1990) Specificity of corticospinal axon arbors sprouting into denervated contralateral spinal cord. J Comp Neurol 302:461-472.

Laemmli UK (1970) Cleavage of structural proteins during the assembly of the head of bacteriophage T4. Nature 227:680-685.

Lagenaur C, Lemmon V (1987) An L1-like molecules, the 6D9 antigen is a potent substrate for neurite extension. Proc Natl Acad Sci USA 84:7753-7757.

Lander C, Zhang H, Hockfield S (1998) Neurons produce a neuronal cell surface-associated chondroitin sulfate proteoglycan. J Neurosci 18:174-183.

Landolt RM, Vaughan L, Winterhalter KH, Zimmermann DR (1995) Versican is selectively expressed in embryonic tissues that act as barriers to neural crest cell migration and axon outgrowth. Development 121:2303-2312.

Li M, Shibata A, Li C, Braun PE, McKerracher L, Roder J, Kater SB, David S (1996) Myelin-associated glycoprotein inhibits neurite/axon growth and causes growth cone collapse. J Neurosci Res 46:404-414.

Margolis RK, Rauch U, Maurel P, Margolis RU (1996) Neurocan and phosphacan: two major nervous tissue-specific chondroitin sulfate proteoglycans. Perspect Dev Neurobiol 3:273-290.

McCarthy KD, de Vellis J (1980) Preparation of separate astroglial and oligodendroglial cell cultures from rat cerebral tissue. J Cell Biol 85:890-902.

McKerracher L, David S, Jackson DL, Kottis V, Dunn RJ, Braun PE (1994) Identification of myelin-associated glycoprotein as a major myelin-derived inhibitor of neurite growth. Neuron 13:805-811.

Meyer-Puttlitz B, Junker E, Margolis RU, Margolis RK (1996) Chondroitin sulfate proteoglycans in the developing central nervous system. II. Immunocytochemical localization of neurocan and phosphacan. J Comp Neurol 366:44-54.

Milev P, Maurel P, Chiba A, Mevissen M, Popp S, Yamaguchi Y, Margolis RK, Margolis RU (1998) Differential regulation of expression of hyaluronan-binding proteoglycans in developing brain: aggrecan, versican, neurocan, and brevican. Biochem Biophys Res Commun 247:207-212.

Miura R, Aspberg A, Ethell IM, Hagihara K, Schnaar RL, Ruoslahti E, Yamaguchi Y (1999) The proteoglycan lectin domain binds sulfated cell surface glycolipids and promotes cell adhesion. J Biol Chem 274:11431-11438.

Morrissey JH (1981) Silver stain for proteins in polyacrylamide gels: a modified procedure with enhanced uniform sensitivity. Anal Biochem 117:307-310.

Mukhopadhyay G, Doherty P, Walsh FS, Crocker PR, Filbin MT (1994) A novel role for myelin-associated glycoprotein as an inhibitor of axonal regeneration. Neuron 13:757-767.

Pesheva P, Gennarini G, Goridis C, Schachner M (1993) The F3/11 cell adhesion molecule mediates the repulsion of neurons by the extracellular matrix glycoprotein J1-160/180. Neuron 10:69-82.

Rauch U, Gao P, Janetzko A, Flaccus A, Hilgenberg L, Tekotte H, Margolis RK, Margolis RU (1991) Isolation and characterization of developmentally regulated chondroitin sulfate and chondroitin/keratan sulfate proteoglycans of brain identified with monoclonal antibodies. J Biol Chem 266:14785-14801.

Schmalfeldt M, Dours-Zimmermann MT, Winterhalter KH, Zimmermann DR (1998) Versican V2 is a major extracellular matrix component of the mature bovine brain. J Biol Chem 273:15758-15764.

Schnell L, Schwab ME (1990) Axonal regeneration in the rat spinal cord produced by an antibody against myelin-associated neurite growth inhibitors. Nature 343:269-272.

Schwab ME, Bartholdi D (1996) Degeneration and regeneration of axons in the lesioned spinal cord. Physiol Rev 76:319-370.

Schwartz NB (1977) Regulation of chondroitin sulfate synthesis. Effect of $\beta$-xylosides on synthesis of chondroitin sulfate proteoglycan, chondroitin sulfate chains, and core protein. J Biol Chem 252:6316-6321.

Schwegler G, Schwab ME, Kapf hammer JP (1995) Increased collateral sprouting of primary afferents in the myelin-free spinal cord. J Neurosci 15:2756-2767.

Seidenbecher CI, Richter K, Rauch U, Fassler R, Garner CC, Gundelfin- 
ger ED (1995) Brevican, a chondroitin sulfate proteoglycan of rat brain, occurs as secreted and cell surface glycosylphosphatidylinositolanchored isoforms. J Biol Chem 270:27206-27212.

Seidenbecher CI, Gundelfinger ED, Bockers TM, Trotter J, Kreutz RM (1998) Transcripts for secreted and GPI-anchored brevican are differentially distributed in rat brain. Eur J Neurosci 10:1621-1630.

Shibata A, Wright MV, David S, McKerracher L, Braun PE, Kater SB (1998) Unique responses of differentiating neuronal growth cones to inhibitory cues presented by oligodendrocytes. J Cell Biol 142:191-202.

Snow DM, Steindler DA, Silver J (1990a) Molecular and cellular characterization of the glial roof plate of the spinal cord and optic tectum: a possible role for a proteoglycan in the development of an axon barrier. Dev Biol 138:359-376.

Snow DM, Lemmon V, Carrino DA, Caplan AI, Silver J (1990b) Sulfated proteoglycans in astroglial barriers inhibit neurite outgrowth in vitro. Exp Neurol 109:111-130.

Snow DM, Watanabe M, Letourneau PC, Silver J (1991) A chondroitin sulfate proteoglycan may influence the direction of retinal ganglion cell outgrowth. Development 113:1473-1485.

Sommer I, Schachner M (1981) Monoclonal antibodies (O1 to O4) to oligodendrocyte cell surfaces: an immunocytological study in the central nervous system. Dev Biol 83:311-327.

Spillmann AA, Bandtlow CE, Lottspeich F, Keller F Schwab ME (1998)
Identification and characterization of a bovine neurite growth inhibitor (bNI-220). J Biol Chem 273:19283-19293.

Thallmair M, Metz GA, Z'Graggen WJ, Raineteau O, Kartje GL, Schwab ME (1998) Neurite growth inhibitors restrict plasticity and functional recovery following corticospinal tract lesions. Nat Neurosci 1:124-131.

Towbin H, Staehelin T, Gordon J (1979) Electrophoretic transfer of proteins from polyacrylamide gels to nitrocellulose sheets: procedure and some applications. Proc Natl Acad Sci USA 76:4350-4354.

Vanek P, Thallmair M, Schwab ME, Kapfhammer JP (1998) Increased lesion-induced sprouting of corticospinal fibres in the myelin-free rat spinal cord. Eur J Neurosci 10:45-56.

Yamada H, Watanabe K, Shimonaka M, Yamaguchi Y (1994) Molecular cloning of brevican, a novel brain proteoglycan of the aggrecan/versican family. J Biol Chem 269:10119-10126.

Yamada H, Fredette B, Shitara K, Hagihara K, Miura R, Ranscht B, Stallcup WB, Yamaguchi Y (1997) The brain chondroitin sulfate proteoglycan brevican associates with astrocytes ensheathing cerebellar glomeruli and inhibits neurite outgrowth from granule neurons. J Neurosci 17:7784-7795.

Z'Graggen W, Metz GA, Kartje GL, Thallmair M, Schwab ME (1998) Functional recovery and enhanced corticofugal plasticity after unilateral pyramidal tract lesion and blockade of myelin-associated neurite growth inhibitors in adult rats. J Neurosci 18:4744-4757. 